\title{
Implementation of Character Education in Higher Education through a Case Study Learning Model in the Pancasila Subject
}

\section{Koko Adya Winata ${ }^{1}$, Tatang Sudrajat ${ }^{2}$, Uus Ruswandi ${ }^{3}$}

Universitas Sangga Buana, Bandung, Indonesia ${ }^{1,2}$, UIN Sunan Gunung Djati, Bandung, Indonesia ${ }^{3}$

adyawinata@gmail.com¹, tatangsudrajat@gmail.com², uusruswandi@gmail.com³

\section{Article History}

accepted 23/03/2021

approved 10/04/2021

published 20/04/2021

\begin{abstract}
Pancasila education is a group of general compulsory courses (MKWU) taught in universities with the aim that students have the character of the Indonesian nation. Building national character is part of the goals of national education which must be carried out continuously at various levels of educational units. This study aims to identify the implementation of character education in higher education through a case study learning model in the Pancasila education course. In the learning process, Pancasila lecturers must be creative in using learning models so that Pancasila values are embedded so that they become student attitudes and characters. Through the case study learning model, the goal of Pancasila education to shape student character is expected to be achieved effectively. The method used in this research is descriptive qualitative method. The research method by collecting and recording detailed data from various problems related to the object of research is then analyzed comprehensively. The results showed that; 1) the case study learning model can improve the cognitive aspects of students towards the values of Pancasila. 2) The case study learning model can improve the student's perspective on the values of Pancasila. 3) The case study learning model can internalize the values of Pancasila into student attitudes and character.
\end{abstract}

Keywords: implementation, character education, higher education, case study model, Pancasila

\begin{abstract}
Abstrak
Pendidikan Pancasila merupakan kelompok mata kuliah wajib umum (MKWU) yang diajarkan di perguruan tinggi dengan tujuan agar mahasiswa memiliki karakter bangsa Indonesia. Membangun karakter bangsa merupakan bagian dari tujuan pendidikan nasional yang harus dilakukan secara terus menerus diberbagai tingkat satuan pendidikan. Penelitian ini bertujuan untuk mengidentifikasi tentang implementasi pendidikan karakter di perguruan tinggi melalui model pembelajaran studi kasus pada mata kuliah pendidikan Pancasila. Pada proses pembelajaran, dosen Pancasila harus kreatif dalam menggunakan model pembelajaran agar nilai-nilai Pancasila tertanam sehingga menjadi sikap dan karakter mahasiswa. Melalui model pembelajaran studi kasus, tujuan pendidikan Pancasila untuk membentuk karakter mahasiswa diharapkan dapat tercapai secara efektif. Metode yang digunakan dalam penelitian ini yaitu metode kualitatif deskriptif. Metode penelitian dengan mengumpulkan dan mencatat data secara terperinci dari berbagai masalah yang berhubungan dengan objek penelitian kemudian dianalisis secara komprehensif. Hasil penelitian menunjukan bahwa; 1) Model pembelajaran studi kasus dapat meningkatkan aspek kognitif mahasiswa terhadap nilai-nilai Pancasila. 2) Model pembelajaran studi kasus dapat meningkatkan aspek apektif mahasiswa terhadap nilainilai Pancasila. 3) Model pembelajaran studi kasus dapat mennginternalisasi nilai-nilai Pancasila menjadi sikap dan karakter mahasiswa.
\end{abstract}

Kata Kunci: implementasi, pendidikan karakter, perguruan tinggi, model studi kasus, Pancasila

Social, Humanities, and Education Studies (SHEs): Conference Series https://jurnal.uns.ac.id/shes

p-ISSN 2620-9284 e-ISSN 2620-9292 


\section{PENDAHULUAN}

Pembentukan karakter harus menjadi perhatian utama dalam proses pendidikan di Indonesia di setiap jenjangnya termasuk di perguruan tinggi. Pelajar dan mahasiswa merupakan generasi bangsa yang harus dipersiapkan melalui proses pendidikan yang dapat membangun insan intelektual dan berkarakter. Untuk itu tujuan pendidikan nasional sebagaimana tercantum dalam Undang-Unadang Sistem Pendidikan Nasional Nomor 20 Tahun 2003 tidak hanya menyiapkan pelajar dan mahasiswa yang memiliki kompetensi di bidang akademik namun diharapkan juga berkepribadian yang baik. Pendidikan nasional berfungsi mengembangkan kemampuan dan membentuk watak serta peradaban bangsa yang bermartabat dalam rangka mencerdaskan kehidupan bangsa, bertujuan untuk berkembangnya potensi peserta didik agar menjadi manusia yang beriman dan bertakwa kepada Tuhan Yang Maha Esa, berakhlak mulia, sehat, berilmu, cakap, kreatif, mandiri, dan menjadi warga negara yang demokratis serta bertanggung jawa. Berdasarkan undang-undang sisdiknas tersebut, setiap jenjang pendidikan harus berupaya untuk mengembangkan potensi pelajar dan mahasiswa baik dalam aspek intelektual, spiritual dan sosial.

Pendidikan karakter sangat erat kaitannya dengan kelangsungan berbangsa dan bernegara. Eksistensi suatu bangsa sangat ditentukan oleh karakter yang dimiliki warga bangsa tersebut. Karakter yang kuat dapat menjadi modal utama bangsa Indonesai dalam percaturan global agar mampu menempatkan dirinya sebagai bangsa yang bermartabat sehingga dapat disegani oleh bangsa-bangsa lain. Oleh karena itu bangsa yang berkarakter merupakan bagian dari tujuan pendidikan nasional yang harus mendapatkan perhatian serius berbagai kalangan terutama insan pendidikan. Tidak diharapkan pelajar dan mahasiswa hanya cerdas secara intelektual namun miskin dalam karakter. Untuk menanamkan karakter di lingkungan pendidikan, pemerintah telah mengeluarkan keputusan melalui peraturan presiden nomor 87 tahun 2017 pasal 3 tentang penguatan pendidikan karakter. Penguatan pendidikan karakter dilaksanakan dengan menerapkan nilai-nilai Pancasila dalam pendidikan karakter terutama meliputi nilai-nilai religius, jujur, toleran, disiplin, bekerja keras, kreatif mandiri, demokratis, rasa ingin tahu, semangat kebangsaan, cinta tanah air, menghargai prestasi, komunikatif, cinta damai, gemar membaca, peduli lingkungan, peduli sosial, dan bertanggungiawab (Republik Indonesia, 2017). Melalui pendidikan Pancasila, internalisasi nilai-nilai karakter diharapkan dapat tertanam secara baik kepada seluruh mahasiswa, sehingga generasi bangsa dapat terbangun karakternya.

Pancasila sebagai ideologi dan pedoman hidup berbangsa bernegara harus dapat dipahami oleh seluruh anak bangsa termasuk mahasiwa. Nilai-nilai yang terkandung dalam Pancasila harus menjadi landasan berpikir, bersikap dan bertindak dalam berinteraksi di masyarakat. Pancasila merupakan sumber utama proses pendidikan karakter karena mengajarkan nilai-nilai yang sangat dibutuhkan dalam melangsungkan kehidupan berbangsa bernegara. Nilai-nilai yang ada dalam Pancasila yaitu nilai kehidupan beragama dan nilai kehidupan sosial. Kedua nilai tersebut merupakan karakter bangsa Indonesia yang harus dilestarikan dan dipertahankan melalui proses pendidikan yang berkesinambungan. Permasalahan yang dihadapi bangsa Indonesia dalam pembangunan karakter bangsa, yaitu: a) Disorientasi dan belum dihayatinya nilai-nilai Pancasila sebagai filosofi dan ideology bangsa, b) Keterbatasan perangkat kebijakan terpadu dalam mewujudkan nilai-nilai esensi Pancasila, c) Bergesernya nilai-nilai etika dalam kehidupan berbangsa dan bernegara, d) Memudarnya kesadaran terhadap nilai nilai budaya bangsa, e) Ancaman disintegrasi bangsa, dan f) Melemahnya kemandirian bangsa (Kemendiknas, 2010). Dengan kurangnya pemahaman terhadap hal di atas, dapat berakibat negatif terhadap munculnya berbagai permasalahan baik yang sifatnya moral individual maupun moral sosial. 
Berdasarkan permasalahan di atas, peneliti meyakini bahwa pendidikan karakter melalui MKWU Pancasila dapat terlaksana secara efektif melalui model pembelajaran studi kasus. Model pembelajaran studi kasus erat sekali hubungannya dan dapat dikatakan sama dengan pembelajaran pemecahan masalah (problem solving teachinglearning), bahkan lingkupnya dapat lebih luas (Sukmadinata \& Syaodih, 2012). Dengan model pembelajaran studi kasus mahasiswa diajak untuk memahami, menganalisa, berpendapat dan menyimpulkan tentang fenomena yang terjadi terkait dengan nilai nilai karakter. Mahasiswa diharapkan mampu mengembangkan kreatifitas berfikirnya agar permasalahan terkait karakter didapatkan solusinya.

\section{METODE}

Metode yang digunakan dalam penelitian ini adalah metode penelitian deskriptif kualitatif. Peneliti melakukan kajian dan identifikasi terhadap data yang diperoleh untuk dianalisis terkait penelitian ini. Teknik pengumpulan data melalui studi literatur dan observasi di lapangan. Peneliti berupaya mencari data melalui berbagai artikel, jurnal dan karya tulis ilmiah yang terpublikasikan dalam berbagai lembaga penelitian. Pada saat yang sama, peneliti sekaligus sebagai pengajar mata kuliah Pancasila. Sehingga dapat langsung merasakan proses yang terjadi berkenaan dengan pendidikan karakter melalui model pembelajaran studi kasus pada mata kuliah Pancasila

\section{HASIL DAN PEMBAHASAN}

\section{Pendidikan Karakter di Perguruan Tinggi}

Pendidikan karakter merupakan hal yang sangat esensial mengingat kedudukannya sebagai jati diri dan watak bangsa. Eksistensi pendidikan karakter harus diwujudkan melalui proses pembelajaran yang terencana dan komprehensif di setiap jenjang pendidikan. Karakter adalah watak, tabiat, akhlak atau kepribadian seseorang yang terbentuk dari hasil internalisasi berbagai kebajikan (virtues) yang diyakini dan digunakan sebagai landasan untuk cara pandang, berpikir, bersikap dan bertindak. Kebajikan terdiri atas sejumlah nilai, moral dan norma. Interaksi seseorang dengan orang lain menumbuhkan karakter masyarakat dan karakter bangsa. (Sulistyarini, 2015). Oleh karena itu pengembangan karakter bangsa hanya dapat dilakukan melalui pengembangan karakter individu. Menurut Lickona, karakter berkaitan dengan konsep moral (moral knowing), sikap moral (moral feelling), dan perilaku moral (moral behavior). Berdasarkan ketiga komponen ini dapat dinyatakan bahwa karakter yang baik didukung oleh pengetahuan tentang kebaikan, keinginan untuk berbuat baik, dan melakukan perbuatan kebaikan Lickona menyatakan bahwa pendidikan karakter adalah suatu usaha yang disengaja untuk membantu seseorang sehingga ia dapat memahami, memperhatikan, dan melakukan nilainilai etika yang inti. Karakter cenderung disamakan dengan personalitas atau kepribadian. Orang yang memiliki karakter berarti memiliki kepribadian (Winata, 2020).

Pendidikan karakter memiliki kesamaan esensi dengan pendidikan moral dan akhlak yang bertujuan agar setiap orang memiliki watak yang baik sehingga masyarakat dan bangsa pun memiliki kepribadian baik. Martabat suatu bangsa dapat dilihat dari seberapa baiknya warga bangsa tersebut dalam mengimplementasikan karakternya dalam kehidupan kesehariannya. Oleh sebab itu, karakter merupakan jati diri atau watak bangsa yang sangat penting untuk dijaga dan dipertahankan dalam melangsungkan kehidupan berbangsa dan bernegara. Mengingat pentingnya nilai-nilai karakter, maka di setiap jenjang pendidikan harus ada mata pelajaran atau mata kuliah yang memberikan pemahaman kepada pelajar dan mahasiswa terkait pembentukan karakter. Dalam pembentukan karakter, peran lembaga pendidikan termasuk perguruan tinggi sangat penting dalam membangun karakter bangsa. Dengan demikian, lulusan perguruan tinggi akan menjadi manusia dengan kualitas ganda baik kualitas profesional sesuai keilmuannya dan kualitas moral yang tinggi, sehingga dapat 
berkiprah sebagai warga negara yang baik sesuai bidang pekerjaannya (Asyanti, 2012).

Perguruan tinggi sebagai lembaga pendidikan jenjang lanjutan setelah pendidikan menengah memiliki tanggung jawab agar setiap lulusannya tidak hanya memiliki kecakapan di bidang ilmu pengetahuan. Perguruan tinggi pun berkewajiban untuk membentuk kecakapan kepribadian mahasiswa seperti beriman, tanggung jawab, hormat, nasionalis dan toleran. Menurut Undang-Undang Nomor 12 Tahun 2012 Pasal 5, bahwa pendidikan tinggi bertujuan:

a) Berkembangnya potensi mahasiswa agar menjadi manusia yang beriman dan bertaqwa kepada Tuhan Yang Maha Esa dan berakhlak mulia, sehat, berilmu, cakap, kreatif, mandiri, terampil, kompeten, dan berbudaya untuk kepentingan bangsa.

b) Dihasilkannya lulusan yang menguasai cabang ilmu pengetahuan dan/atauteknologi untuk memenuhi kepentingan nasional dan daya saing bangsa.

c) Dihasilkan ilmu pengetahuan dan teknologi melalui penelitian yang memperhatikan dan menerapkan nilai humaniora agar bermanfaat bagi kemajuan bangsa serta kemajuan peradaban dan kesejahteraan umat manusia, dan

d) Terwujudnya pengabdian kepada masyarakat berbasis penalaran dan karya penelitian yang bermanfaat dalam memajukan kesejahteraan umum dan mencerdaskan kehidupan bangsa.

Berdasarkan butir pasal tersebut, perguruan tinggi memiliki tanggung jawab besar untuk membentuk pribadi mahasiswa yang berkarakter/berkepribadian melalui proses pembelajaran yang terprogram. Mahasiswa diharapkan memiliki pemahaman tentang moral knowing, moral feelling dan moral doing. Sehingga karakter dasar dapat dipahami secara baik dan menjadi kepribadian setiap mahasiswa yang mampu diimplementasikan dalam kehidupannya. Mahasiswa yang berkarakter adalah mahasiswa yang cinta kepada tuhannya yang diwujudkan dalam ketaatan beribadah sesuai keyakinannya. Karakter lain yang harus dimiliki mahasiswa yaitu tanggung jawab dalam setiap perbuatannya, disiplin dalam menjalankan tugas sebagai mahasiswa baik di kampus maupun di luar kampus, hormat dan santun terhadap sesama dengan tidak memandang ras, agama dan golongan. Karakter lain yang ditanamkan di perguruan tinggi yakni menjunjung tinggi persatuan dan cinta tanah air. Jiwa nasionalisme mahasiswa harus dibentuk agar semangat kebangsaan menjadi watak hidupnya. Pasal 3 UU No 12 Tahun 2012 tentang pendidikan tinggi menyatakan, pendidikan tinggi berasakan: a) kebenaran ilmiah, b) penalaran, c) kejujuran, d) keadilan, e) manfaat, f) kebajikan, g) tanggungjawab, h) kebhinekaan dan i) keterjangkauan.

Secara spesifik ada Sembilan (9) karakter dasar yang ingin dicapai dalam pendidikan karakter di perguruan tinggi, yaitu: (Arismantoro, 2008).

a. Cinta kepada Allah dan semesta beserta isinya.

b. Tanggung jawab, disiplin, dan mandiri.

c. Jujur.

d. Hormat dan santun.

e. Kasih sayang, peduli, dan kerjasama.

f. Percaya diri, kreatif, kerja keras, dan pantang menyerah.

g. Keadilan dan kepemimpinan.

h. Baik dan rendah hati.

i. Toleransi, cinta damai dan persatuan

Pembentukan Karakter di Perguruan Tinggi Melalui Pendidikan Pancasila

Pendidikan Pancasila merupakan kelompok mata kuliah MKWU yang diajarkan di perguruan tinggi yang pada prinsipnya secara keseluruhan materi pelajarannya 
mengandung nilai-nilai karakter. Karakter yang hendak dicapai dari pendidikan Pancasila adalah mahasiswa yang memiliki karakter individual dan sosial. Mahasiswa diharapkan memiliki pengetahuan teologis dan sosiologis yang dimanifestikan dengan menjalankan agamanya dan senantiasa bersikap toleran kepada pemeluk agama lainnya. Secara spesifik tujuan penyelenggaraan Pendidikan Pancasila di Perguruan Tinggi adalah untuk: (Kemendikbud, 2013).

1. Memperkuat Pancasila sebagai dasar falsafah negara dan ideologi bangsa melalui revitalisasi nilai-nilai dasar Pancasila sebagai Norma dasar kehidupan bermasyarakat, berbangsa dan bernegara.

2. Memberikan pemahaman dan penghayatan atas jiwa dan nilai-nilai dasar Pancasila kepada mahasiswa sebagai warga negara Republik Indonesia, serta membimbing untuk dapat menerapkannya dalam kehidupan bermasyarakat, berbangsa dan bernegara.

3. Mempersiapkan mahasiswa agar mampu menganalisis dan mencari solusi terhadap berbagai persoalan kehidupan bermasyarakat, berbangsa dan bernegara melalui sistem pemikiran yang berdasarkan nilai-nilai Pancasila dan UUD NRI Tahun 1945.

4. Membentuk sikap mental mahasiswa yang mampu mengapresiasi nilai-nilai ketuhanan, kemanusiaan, kecintaan pada tanah air dan kesatuan bangsa, serta penguatan masyarakat madani yang demokratis, berkeadilan, dan bermartabat berlandaskan Pancasila, untuk mampu berinteraksi dengan dinamika internal dan eksternal masyarakat bangsa Indonesia.

Setiap mahasiswa yang mengikuti mata kuliah pendidikan Pancasila dipastikan akan mendapatkan materi tentang Pancasila sebagai system etika, Pancasila sebagai alat pemersatu bangsa, Pancasila sebagai ideology negara, Pancasila sebagai sumber hukum bangsa, Pancasila sebagai Falsafah negara dan Pancasila sebagai karakteristik HAM dan demokrasi. Materi Pendidikan Pancasila tersebut sangat erat kaitannya dengan nilai-nilai karakter yang dibutuhkan dalam melangsungkan kehidupan berbangsa dan bernegara. Sehingga pendidikan Pancasila sering disebut sebagai pendidikan karakter kebangsaan (nation character). Setiap sila dalam Pancasila mengandung nilai yang sangat penting untuk dipahami dan diimplemntasikan. Lima sila dalam Pancila merupakan nilai dasar yang bersifat satu kesatuan utuh yang tidak bisa dipisahkan dan mencerminkan karakter kebangsaan. Setiap sila pancasila merupakan suatu nilai sehingga Pancasila disebut sebagai falsafah negara. Oleh karena itu, sila-sila pancasila itu pada hakikatnya merupakan suatu kesatuan, meskipun antara sila yang satu dengan sila yang berbeda, tetapi kesemuanya merupakan kesatuan yang sistematis (Chairiyah, 2014).

Nilai-nilai karakter yang ada dalam pendidikan Pancasila dapat dipahami dari seluruh proses pembelajaran materi pendidikan Pancasila yang mencakup dimensi realitas, dimensi idealitas dan dimensi fleksibilitas Pancasila. Dimensi realitas Pancasila itu menunjukan bahwa; a) Bangsa Indonesia meyakini adanya tuhan hal itu ditegaskan dalam sila pertama "ketuhanan yang Maha Esa".b) Bangsa Indonesia menjunjung tinggi nilai-nilai kemanusian sesuai dengan amanat sila kedua. Hal itu ditunjukkan melalui sikap saling tolong menolong, simpati dan empati baik dalam lingkup nasional maupun global, c) Menjunjung tinggi persatuan dan kesatuan baik dalam percaturan nasional maupun dunia. Sikap tersebut ditunjukkan melalui hubungan diplomasi untuk menyelesaikan konflik, d) Mengedepankan musyawarah dalam menyelesaikan suatu permasalahan dengan dasar kebijaksanaan, e) Mewujudkan rasa keadilan melalui program-program yang langsung dapat dirasakan oleh masyarakat banyak. Dimensi idealitas Pancasila meliputi: a) Pancasila merupakan Nilai dan Moral Yang Hendak Dicapai Bangsa, b) Sumber Kekuatan dalam Berbangsa, c) Nilai-nilai dasar Pancasila Mengandung Tujuan Hidup Berbangsa. d) Sumber Motivasi dalam Berbangsa dan Bernegara, e) Sumber Edukasi dalam Kehidupan 
Manusia. Dan yang menjadi dimensi fleksibitas Pancasila adalah; a) Relevan dengan Dinamika Kehidupan, b) Pancasila Sebagai Ideologi Terbuka, c) Menghargai pemikiran yang berkemajuan, d) Mengembangkan Budaya Kritis yang Konstruktif. e) Menghargai Keberagaman. Ketiga dimensi yang ada dalam Pancasila tersebut mencerminkan nilainilai karakter yang harus dijaga dan dilestarikan melalui proses pembelajaran yang terus menerus di setiap jenjang pendidikan termasuk di perguruan tinggi. Maka untuk mewujudkan hal itu diperlukan kreatifitas dalam menggunakan model atau metode pembelajarannya.

\section{Implementasi Model Pembelajaran Studi Kasus Pendidikan Pancasila}

Model pembelajaran merupakan cara penyajian bahan ajaran yang digunakan guru atau dosen sebagai acuan dan pedoman belajar pada saat menyampaikan bahan pelajaran kepada siswa atau mahasiswa baik secara individual maupun secara kelompok. Model pembelajaran yang dipergunakan dapat menentukan efektif tidaknya proses pembelajaran dan berhasilnya tujuan pembelajaran. Model pembelajaran merupakan salah satu hal yang sangat penting di dalam proses kegiatan belajar mengajar untuk menunjang keberhasilah belajar. Proses pembelajaran akan berlangsung baik, menarik dan dapat memotivasi minat peserta didik diantaranya karena ketepatan model pembelajaran yang digunakan. Peserta didik akan terbantu dalam proses pembelajaran karena model pembelajaran akan mendorong aktifitas siswa dalam belajar. (Winata, 2021). Pemilihan terhadap model pembelajaran harus menjadi perhatian setiap dosen pendidikan Pancasila agar tujuan pembelajaran dapat tercapai secara efektif. Pada prinsipnya proses pembelajaran pendidikan Pancasila bertujuan agar mahasiswa memiliki kemampuan kognitif, afektif dan konatif terhadap nilai-nilai Pancasila.

Model pembelajaran yang dipandang efektif dalam menanamkan nilai-nilai Pancasila sebagai karakter kebangsaan (nation character) kepada setiap mahasiswa yakni dengan menggunakan model pembelajaran studi kasus. Model ini sangat menekankan kepada upaya pengembangan kreatifitas berfikir mahasiswa karena setiap materi yang disampaikan harus disertai dengan contoh peristiwa yang bersifat faktual. Dalam hal ini, mahasiswa dituntut untuk berfikir kritis terhadap materi pelajaran pendidikan Pancasila, menemukan contoh kasus dan menganalisanya melalui proses diskusi yang intens untuk menjelaskan tema bahasan. Dengan demikian, model pembelajaran studi kasus dapat meningkatkan daya berfikir kritis mahasiswa terkait materi pendidikan Pancasila. Daya berfikir kritis mahasiswa diasah melalui pembelajaran studi kasus. Setiap proses pembelajaran materi pelajaran pendidikan Pancasila dilaksanakan tidak hanya sebatas transfer of knowlage melainkan telaah kritis dan case study. Sehingga mahasiswa dapat memiliki moral knowing, moral felling dan moral doing terkait nilai-nilai Pancasila.

Kriteria berpikir kritis dikelompokkan dalam Lima indikator yaitu: (1) klasifikasi dasar (elementary clarification); (2) memberikan alasan untuk suatu keputusan (the basic of the decison); (3) menyimpulkan (inference); (4) klarifikasi lebih lanjut (advanced clarification); (5) dugaan dan keterpaduan (strategi and tactic) (Ennis dalam Afrizon, 2012). Model studi kasus dapat mempertajam kemampuan analisis, pemecahan masalah dan pengambilan keputusan. Meningkatkan pemahaman tentang system nilai, persepsi, dan sikap mahasiswa terkait dengan situasi/kasus Menunjukkan kepada mahasiswa peranan dan pengaruh nilai dan persepsi terhadap pengambilan keputusan. Menumbuhkan sinergi kelompok dalam memecahkan suatu masalah. Internalisasi Nilai Ketuhanan Yang Maha Esa Melalui Studi Kasus

Pancasila merupakan satu kesatuan yang setiap sila dari Pancasila saling terkait dan tidak bisa dipisahkan. Pancasila adalah filsafat negara Indonesai sebagai collective ideologies bangsa Indonesia. Pancasila telah menjadi realitas kehidupan bangsa Indonesia yang terjawantahkan dalam setiap sila Pancasila. Pancasila merupakan system nilai dan ajaran yang bersifat universal. Sila pertama Pancasila 
adalah ketuhanan yang maha esa, yakni bangsa Indonesia meyakini adanya aspek religiusitas yang tercermin dengan penghambaan kepada Tuhan. Model studi kasus yang dilakukan dalam rangka internalisasi nilai ketuhanan melalui proses diskusi yang bertujuan untuk memberikan pemahaman kepada mahasiswa tentang makna tuhan baik dalam konteks moral individual maupun sosial. Model studi kasus bertujuan membahas aspek ketuhanan dapat dilakukan melalui pembagian kelompok mahasiswa seperti kelompok A, B, C dan D. Setiap kelompok mendiskusikan tema terkait aspek teologis atau ketuhanan yang tema diskusinya ditentukan oleh dosen pendidikan Pancasila.

Dalam proses diskusi tersebut setiap anggota kelompok diskusi berpartisipasi aktif dengan memberikan tanyajawab dan tanggapan serta menganalisisnya disertai contoh kasus yang relevan. Seperti mengapa harus menyembah tuhan, Apa tujuan Tuhan Menciptakan manusia? Maka jawaban atau tanggapan dari pertanyaan tersebut dapat disertai contoh kasus yang dinarasikan sehingga dapat memudahkan dalam memahaminya. Melalui model pembelajaran studi kasus mahasiswa diharapkan dapat memahami makna tuhan sebagai sumber energy, inspirasi dan motivasi dalam bersikap baik ketika sedang sendiri mapun sedang berada dengan orang banyak. Maka nilai-nilai ketuhanan akan menjadi karakter mahasiswa yang menjadi landasan berfikir, berucap dan bersikap serta berprilaku dalam kehidupannya. Dengan memahami aspek teologis, mahasiswa diharapkan memilki kepribadian atau watak tawazun yakni keseimbangan.

Karakter tawazun dapat membentuk pribadi mahasiswa yang mampu memadukan keberhasilan hidup dunia dan akhirat. Adapun nilai-nilai karakter yang terkandung dalam sila pertama antara lain sebagai berikut: (Saragih, 2017).

1. Keyakinan terhadap adanya Tuhan yang Maha Esa dengan sifat-sifatnya yang Maha sempurna.

2. Ketakwaan terhadap Tuhan Yang Maha Esa, dengan cara menjalankan semua perintah-Nya dan sekaligus menjauhi segala larangan-Nya.

3. Saling menghormati dan toleransi antara pemeluk agama yang berbeda-beda.

4. Kebebasan menjalankan ibadah sesuai dengan agama dan kepercayaannya

Internalisasi Nilai Kemanusiaan Yang Adil Dan Beradab Melalui Studi Kasus

Kemanusiaan yang adil dan beradab merupakan sila kedua Pancasila yang

harus menjadi pengetahuan mahasiswa sekaligus harus diamalkan dalam kehidupannya. Tujuan yang hendak dicapai dengan memahami sila kedua Pancasila yakni mahasiswa memiliki sikap dan watak yang menjunjung tinggi nilai kemanusian tanpa memandang agama, ras dan golongan. Untuk menginternalisasikan nilai kemanusian tersebut dilakukan melalui model pembelajaran studi kasus yang bersifat factual dan relevan. Model pembelajaran studi kasus dilakukan dengan mengajak mahasiswa untuk berfikir kritis, diantarnya dengan memahami makna kemanusiaan dengan menyebutkan contoh tindakan yang mencerminkan kemanusiaan dan atau tindakan yang bertentangan dengan nilai-nilai kemanusiaan. Mahasiswa memahami fakta yang sesungguhnya akibat negative dari tindakan yang tidak memperhatikan nilai-nilai kemanusiaan.

Melalui model pembelajaran studi kasus diharapkan dapat membentuk karakter mahasiswa yang utuh dan permanen dalam memahami nilai-nilai kemanusiaan. Sehingga karakter mahasiswa senantiasa menjunjung tinggi nilai kemanusiaan. Nilai Pancasila sila kedua tentang kemanusiaan yang adil dan beradab dapat dipahami sebagai berikut: (1) Mengakui dan memperlakukan manusia sesuai dengan harkat dan martabanya sebagai makhluk Tuhan Yang Maha Esa. (2) Mengakui persamaan derajat, persamaan hak dan persamaan kewajiban antara sesama manusia. (3) Saling mencintai sesama manusia; (4) Mengembangkan sikap tenggang rasa, (5) Mengembangkan sikap tidak semena-mena terhadap orang lain; (6) Menjunjung tinggi nilai kemanusiaan; (7) Gemar melakukan kegiatan kemanusiaan; (8) Berani membela 
keadilan dan kebenaran; (9) Bangsa Indonesia merasa dirinya sebagai bagian dari seluruh umat manusia; dan (10) Mengembangkan sikap hormatmenghormati dan bekerjasama dengan bangsa lain (Rianto, 2016).

\section{Internalisasi Nilai Persatuan Melalui Studi Kasus}

Sila ketiga Pancasila adalah persatuan Indonesia yang harus dipahamkan dan diinternalisasikan kepada setiap mahasiswa ketika mengikuti mata pelajaran pendidikan Pancasila. Tujuan pembelajaran dari materi ini yaitu hendak memahamkan pentinnya nilai persatuan dalam membangun bangsa dan bernegara. Mahasiswa diharapkan memiliki kepahaman dan kesadaran yang utuh terkait nilai persatuan sehingga menjadi watak dan sikapnya. Model studi kasus dalam rangka memahami materi nilai persatuan yakni dengan mendiskusikan dan menyertakan contoh kasusnya. Mahasiswa diharapkan mampu memahami, mengobservasi dan menganalisa dengan menyebutkan contoh kasus konflik dan pertentangan berikut dampak negative yang ditimbulkan. Konflik dan pertentangan yang muncul karena kepentingan golongan atau kedaerahan manakala tidak segera diantisipasi dapat mengancam keutuhan negara. Konflik dan permusuhan hanya dapat menimbulkan kerugian dan kesengsaraan bagi seluruh lapisan masyarakat.

Pertentangan ideology, suku dan agama seperti yang terjadi di Irak, Syria dan sebagian negara Afrika hanya menimbulkan kerugian dan kesengsaran yang berkepanjangan. Mahasiswa diajak untuk berfikir kritis melalui studi kasus dengan memahami peristiwa konflik di negara lain sehingga setiap mahasiswa memiliki keasadaran dan tekad untuk menjaga nilai pesatuan dan kesatuan. Cinta persatuan, mendahulukan kepentingan bangsa dan negara diharapkan dapat menjadi kepribadian dan watak serta karakter mahasiswa. Sila Persatuan Indonesia merujuk pada persatuan yang utuh dan tidak terpecah belah atau bersatunya bermacam-macam perbedaan suku, agama, antar golongan dan lain-lain yang berada di wilayah Indonesia. Sila Persatuan Indonesia merupakan kristalisasi sejarah bangsa Indonesia yang pernah dibuktikannya pada masa penjajahan setelah perjuangan kedaerahan dirasa tidak berhasil (Hanafi, 2018).

\section{Internalisasi Nilai Permusyawaratan Melalui Studi Kasus}

Nilai permusyarawatan merupakan materi pendidikan Pancasila yang bertujuan agar mahasiswa senantiasa mendahulukan musyawarah dengan membuka ruang dialog manakala terjadi perbedaan pandangan. Mahasiswa diajak untuk mencermati dan memahami manfaat musyawarah dalam berbagai kesempatan untuk mencari solusi dari sebuah perbedaan. Indonesia sebagai negara yang heterogen dan memiliki kemajemukan dalam berbagai sisi baik agama, ras, suku, Bahasa dan budaya kalau tidak dikelola dengan baik dapat menjadi pemicu munculnya konflik. Oleh karena itu, musyawarah harus menjadi karakter mahasiswa yang diyakini sebagai upaya untuk mencari titik temu terhadap perbedaan yang muncul di tengah-tengah masyarakat.

Model studi kasus dalam menginternalisasikan nilai permusyawaratan kepada mahasiswa yakni setiap mahasiswa diajak untuk berfikir kritis melalui diskusi kelompok terhadap fenomena perbedaan yang ada di masyarakat Seperti perbedaan agama terkadang menjadi konflik di sebagian masyarakat yang berakibat hancurnya tatanan sosial kemasyarakatan dan bahkan dapat menimbulkan disintegrasi bangsa. Untuk itu, kajian kritis terhadap fenomena perbedaan agama, ras, suku dan budaya dilakukan dengan senantiasa mendahulukan dialog atau musyawarah. Nilai musayawarah mufakat pada dasarnya adalah usaha untuk mencari hakekat kebenaran, keadilan, kesempurnaan tertinggi dan terbaik dalam proses pengambilan keputusan melalui suatu mekanisme yang damai dengan mengedepankan etika yang sesuai dengan kelaziman dan kepatutan. Kelaziman dan kepatutan yang dimaksud adalah yang sesuai dengan agama, etika dan moral yang menjadi tradisi yang hidup dan berkembang dalam masyarakat Indonesia (Herlambang, 2017). 


\section{Internalisasi Nilai Keadilan Sosial Melalui Studi Kasus}

Nilai keadilan sosial harus menjadi karakter mahasiswa yang ditanamkan melalui proses pembelajaran pendidikan Pancasila yang terprogram. Keadilan sosial tidak hanya sebatas slogan dan jargon-jargon politik yang mengemuka ketika pesta demokrasi berlangsung. Keadilan sosial merupakan nilai yang harus diwujudkan dalam kehidupan berbangsa dan bernegara dengan senantiasa memperhatikan dan mendahulukan kepentingan umum di atas kepentingan pribadi dan golongan. Keadilan menjadi syarat mutlak yang harus dipenuhi dalam menjaga keutuhan hubungan berbangsa dan bernegara. Masyarakat dan negara jauh dari kehidupan harmonis dan tentram manakala masing-masing warga atau penduduknya serta pemerintahnya tidak berlaku adil. Keadilan adalah sifat tidak berat sebelah, tidak memihak, berpihak kepada yang benar, berpegang kepada kebenaran sepatutnya dan tidak sewenang-wenang.

Secara etimologis, keadilan adalah kondisi kebenaran ideal secara moral mengenai sesuatu hal, baik menyangkut benda atau orang. Keadilan sosial harus diterapkan di setiap bidang kehidupan sosial-ekonomi dan politik tanpa diskriminasi. Akibatnya, semua kegiatan pribadi yang bertentangan dengan konsep prinsip dasar ini, seperti monopoli, penyakit nepotisme dan konspirasi tidak boleh dibiarkan (Herawati, 2014). Pemahaman terhadap nilai keadilan dapat dilakukan melalui model pembelajaran studi kasus pada mata kuliah pendidikan Pancasila. Mahasiswa melakukan diskusi kelompok dengan melakukan telaah kritis terhadap fenomena ketidak adilan yang terjadi di masyarakat

\section{SIMPULAN}

Berdasarkan paparan di atas, pembentukan karakter harus menjadi perhatian utama dalam proses pendidikan di Indonesia di setiap jenjangnya termasuk di perguruan tinggi. Pelajar dan mahasiswa merupakan generasi bangsa yang harus dipersiapkan melalui proses pendidikan yang dapat membangun insan intelektual dan berkarakter. Perguruan tinggi pun berkewajiban untuk membentuk kecakapan kepribadian mahasiswa seperti beriman, tanggung jawab, hormat, nasionalis dan toleran. Melalui pendidikan Pancasila mahasiswa diharapkan memiliki karakter kebangsaan. Sehingga pendidikan Pancasila sering disebut sebagai pendidikan karakter kebangsaan (nation character). Lima sila dalam Pancila merupakan nilai dasar yang bersifat satu kesatuan utuh yang tidak bisa dipisahkan dan mencerminkan karakter kebangsaan. Untuk menginternalisasikan nilai Pancasila tersebut dapat dilakukan melalui model pembelajaran studi kasus. Model ini sangat menekankan kepada upaya pengembangan kreatifitas berfikir mahasiswa karena dalam proses pembelajarnnya lebih banyak melakukan diskusi. Setiap mahasiswa harus berupaya untuk menganalisa materi pendidikan Pancasila disertai dengan contoh peristiwa yang bersifat faktual. Sehingga mahasiswa diharapkan memiliki moral knowing, moral feeling dan moral doing. Model pembelajaran studi kasus diyakini dapat meningkatkan kemampuan mahasiswa baik dalam aspek kognitif, afektif dan konatif terhadap nilainilai yang terkandung dalam Pancasila.

\section{DAFTAR PUSTAKA}

Afrizon, R. (2012). Peningkatan perilaku berkarakter dan keterampilan berpikir kritis siswa kelas IX MTsN model Padang pada mata pelajaran IPA-Fisika menggunakan model problem based intruction. Jurnal Penelitian Pembelajaran Fisika. Vol. 1 No. 2. 1-16

Arismantoro. (2008). Tinjauan Berbagai Aspek Character Building: Bagaimana Mendidik Anak Berkarakter. Yogyakarta: Tiara Wacana.

Asyanti S., (2012). Pendidikan Karakter Di Perguruan Tinggi: Sudah Terlambatkah? Prosiding Seminar Nasional Psikologi Islami. 284-291.

Chairiyah. (2014). Revitalisasi Nilai-Nilai Pancasila Sebagai Pendidikan Karakter. Trihayu: Jurnal Pendidikan Ke-Sd-An, Vol. 1. No. 1. 54-62. 
Hanafi. (2018). Hakekat Nilai Persatuan Dalam Konteks Indonesia (Sebuah Tinjauan Kontekstual Positif Sila Ketiga Pancasila). Jippk, Volume 3, Nomor 1, 56-63

Herawati, Y. (2014). Konsep Keadilan Sosial Dalam Bingkai Sila Kelima Pancasila (The Concept Of Social Justice Within The Fifth Principle Framework Of Pancasila). Volume 18, Nomor 1, 20-27.

Herlambang. (2017). Perwujudan Sila Ke Empat Pancasila Setelah Perubahan Undang-Undang Dasar 1945. Jurnal Penelitian Hukum. Vol. 26, No. 2, 51-68.

Kementerian Pendidikan Nasional. 2010. Rencana Induk Pengembangan Pendidikan KarakterBangsa. Jakarta: Kementerian Pendidikan Nasional.

Republik Indonesia. (2017). Peraturan presiden republik Indonesia nomor 87 Tahun 2017 tentang Penguatan pendidikan karakter. Jakarta: Sekretariat Negara. Retrievedfromhttp://setkab.go.id/wpcontent/uploads/2017/09/Perpres_Nomor_8 7_Tahun_2017.pdf

Rianto, $\bar{H}$. 2016. Implementasi Nilai Kemanusiaan Yang Adil Dan Beradab Di Lingkungan Sekolah. Sosial. Horizon: Jurnal Pendidikan Sosial, Vol. 3, No. 1. 80-91.

Saragih, E. 2017. Analisis Dan Makna Teologi Ketuhanan Yang Maha Esa Dalam Konteks Pluralisme Agama Di Indonesia. Jurnal Teologi, Vol 2, No. 1, 1-13

Sugilar, H., Kariadinata, R., Farlina, E., dan Gunawan, H. (2018). Membangun Karakter Mahasiswa Melalui Nilai-Nilai Matematika, MaPan: Jurnal Matematika dan Pembelajaran, Volume 6, No 2, 161-172.

Sukmadinata, N \& Syaodih. (2012). Kurikulum \& pembelajaran kompetensi. Bandung: Refika Aditama

Sulistyarini. (2015). Pengembangan Karakter Berbasis Pancasila Melalui Pendidikan Kewarganegaraan. Jurnal Bhinneka Tunggal lka, Volume 2, Nomor 1, 1-8.

Sumarto.(2018). Pancasila Membentuk Pendidikan Karakter Bangsa Melalui Proses Pendidikan Keislaman. Jurnal Nizham, Vol. 06, No. 01, 59-66.

Winata, K. A., Hasanah, A. (2021). Implementasi Model Pembelajaran Interaksi Sosial UntukMeningkatkan Karakter Peserta Didik. Jurnal Pendidikan, Vol.9, No.1, 2232. 